\title{
Omvang risicogroepen in de Limburgse gemeente Horst aan de Maas
}

Citation for published version (APA):

Künn, A., \& Poulissen, D. (2019). Omvang risicogroepen in de Limburgse gemeente Horst aan de Maas. ROA. ROA Fact Sheets No. 003-5961 https://doi.org/10.26481/umarof.2019003-5961

Document status and date:

Published: 27/03/2019

DOI:

10.26481/umarof.2019003-5961

Document Version:

Publisher's PDF, also known as Version of record

\section{Please check the document version of this publication:}

- A submitted manuscript is the version of the article upon submission and before peer-review. There can be important differences between the submitted version and the official published version of record.

People interested in the research are advised to contact the author for the final version of the publication, or visit the DOI to the publisher's website.

- The final author version and the galley proof are versions of the publication after peer review.

- The final published version features the final layout of the paper including the volume, issue and page numbers.

Link to publication

\footnotetext{
General rights rights.

- You may freely distribute the URL identifying the publication in the public portal. please follow below link for the End User Agreement:

www.umlib.nl/taverne-license

Take down policy

If you believe that this document breaches copyright please contact us at:

repository@maastrichtuniversity.nl

providing details and we will investigate your claim.
}

Copyright and moral rights for the publications made accessible in the public portal are retained by the authors and/or other copyright owners and it is a condition of accessing publications that users recognise and abide by the legal requirements associated with these

- Users may download and print one copy of any publication from the public portal for the purpose of private study or research.

- You may not further distribute the material or use it for any profit-making activity or commercial gain

If the publication is distributed under the terms of Article $25 \mathrm{fa}$ of the Dutch Copyright Act, indicated by the "Taverne" license above, 
Maastricht University $\&$ ROA

\section{Omvang risicogroepen in de Limburgse gemeente Horst aan de Maas}

Annemarie Künn

Davey Poulissen

\section{ROA Factsheet}

ROA-F-2019/3 - Horst aan de Maas

Researchcentrum voor Onderwijs en Arbeidsmarkt | ROA Research Centre For Education and the Labour Market / ROA 


\section{Omvang risicogroepen in de Limburgse gemeente Horst aan de Maas}

\section{Snelle feiten en cijfers ${ }^{1}$}

1. Ongeveer $14,4 \%$ van de 15 tot en met 67 -jarige inwoners van de gemeente Horst aan de Maas bevindt zich in een risicopositie omdat zij een arbeidsongeschiktheids-, werkloosheids- of bijstandsuitkering ontvangen, of omdat zij inactief zijn op de arbeidsmarkt.

2. Het percentage personen dat zich in een risicopositie bevindt, is binnen de gemeente Horst aan de Maas het hoogst in de wijk Evertsoorsd (27,6\%).

\section{Inleiding}

In december 2018 is een factsheet gepubliceerd waarin de omvang van de risicogroepen in Limburg in kaart is gebracht op peildatum 31 december $2015 .^{2}$ Voortbouwend op deze zogenaamde nulmeting, bekijken we in deze factsheet de situatie in de gemeente Horst aan de Maas op 31 december 2017. De gemeente Horst aan de Maas telde op 31 december 2017, 28.145 inwoners die tot de potentiële beroepsbevolking behoorden én op 31 december 2015 reeds in Nederland woonachtig waren. ${ }^{3}$ Dat wil zeggen dat zij, gezien hun leeftijd, in principe actief zouden kunnen zijn op de arbeidsmarkt. ${ }^{4}$ Een deel van deze inwoners bevindt zich echter in een risicopositie omdat zij uitkeringsafhankelijk en/of niet actief op de arbeidsmarkt zijn. Daardoor is hun financiële positie vaak ook zwak en lopen ze op termijn een groter risico op langdurige uitkeringsafhankelijkheid en maatschappelijke uitsluiting.

1 Tot de gemeente Horst aan de Maas behoren (in 2017) de volgende wijken: America, Broekhuizen, Broekhuizen, Evertsoorsd, Griendtsveen, Grubbenvorst, Hegelsom, Horst, Kronenberg, Lottum, Meerlo, Melderslo, Meterik, Sevenum, Swolgen en Tienray.

2 Zie: ROA (2018) Omvang risicogroepen in Limburg, ROA-F2018/20.

3 Mensen die tussen 31 december 2015 en 31 december 2017 geïmmigreerd zijn vallen dus buiten het bereik van deze factsheet. Deze toevoeging wordt in de rest van de factsheet niet herhaald.

4 De potentiële beroepsbevolking wordt door ons gedefinieerd als alle inwoners in de leeftijd 15 tot en met 67 jaar.
In deze factsheet maken we voor de gemeente Horst aan de Maas inzichtelijk wat de absolute en relatieve omvang is van een viertal groepen inwoners met een risicopositie, namelijk:

1. Personen met een arbeidsongeschiktheidsuitkering

2. Personen met een werkloosheidsuitkering

3. Personen met een bijstandsuitkering

4. Personen die inactief zijn zonder dat zij onderwijs volgen of één of meerdere van de hierboven genoemde uitkeringen ontvangen. Personen die de AOW-gerechtigde leeftijd hebben bereikt of een pensioenuitkering ontvangen worden niet als inactief bestempeld.

Omdat het mogelijk is dat inwoners naast het ontvangen van de drie genoemde uitkeringstypes werken, brengen we tevens in kaart welk deel van de uitkeringsafhankelijken naast hun uitkering betaald werk verricht. Personen die naast het ontvangen van een uitkering betaald werk verrichten lopen om allerhande redenen minder risico. Allereerst wordt hun uitkering aangevuld door inkomen uit werk, waardoor hun financiële positie over het algemeen beter zal zijn dan zonder deze inkomsten. Daarnaast kan het feit dat zij actief zijn op de arbeidsmarkt het risico op maatschappelijke uitsluiting verkleinen. Tot slot kan het feit dat zij betaald werk verrichten het risico op langdurige uitkeringsafhankelijkheid verminderen.

Om de cijfers voor de gemeente Horst aan de Maas in context te plaatsen, vergelijken we deze met cijfers voor de provincie Limburg als geheel, de verschillende COROP-regio's (Noord-, Midden- en Zuid-Limburg) en Nederland als geheel. Deze factsheet geeft daarmee de omvang van de verschillende risicogroepen in de gemeente Horst aan de Maas weer en vergelijkt deze met de genoemde referentieregio's. Dit is een belangrijke eerste stap alvorens bekeken kan worden wat de specifieke (en complexe) problematiek is van de mensen die tot deze risicogroepen behoren en in hoeverre re-integratiebeleid uitstroom uit een risicosituatie kan stimuleren. 


\section{Inwoners met een arbeidsongeschiktheidsuitkering}

TABEL1.

Overzicht van de absolute en relatieve omvang van inwoners met een arbeidsongeschiktheidsuitkering (AO-uitkering)

\begin{tabular}{|l|r|r|r|r|}
\hline & Aantal inwoners met een & Aantal inwoners behorend tot de & $\begin{array}{r}\text { Percentage inwoners met een } \\
\text { potentiële beroepsbevolking }\end{array}$ & $\begin{array}{r}\text { Percentage werkende onder } \\
\text { A0-uitkering }\end{array}$ \\
inwoners met een A0-uitkering \\
\hline Gemeente Horst aan de Maas & 1.409 & 28.145 & $5 \%$ & $25,8 \%$ \\
\hline Noord-Limburg & 12.364 & 187.721 & $6,6 \%$ & $20,6 \%$ \\
\hline Midden-Limburg & 12.629 & 157.217 & $8 \%$ & $17,7 \%$ \\
\hline Zuid-Limburg & 39.810 & 395.604 & $10,1 \%$ & $15 \%$ \\
\hline Limburg totaal & 64.803 & 740.542 & $8,8 \%$ & $16,6 \%$ \\
\hline Nederland totaal & 727.889 & $6,4 \%$ & $17,9 \%$ \\
\hline
\end{tabular}

Bron: $\mathrm{ROA}$, berekeningen op basis van microdata van het CBS

Tabel 1 geeft een overzicht van de omvang van het aantal personen met een arbeidsongeschiktheidsuitkering in de gemeente Horst aan de Maas. Om de cijfers voor Horst aan de Maas in context te plaatsen worden ze ook vergeleken met de cijfers voor de provincie Limburg als geheel en de drie onderliggende COROP-regio's Noord-, Midden- en ZuidLimburg.

Uit Tabel 1 zijn een aantal conclusies te trekken:

- De gemeente Horst aan de Maas telde op 31 december 2017, 1.409 inwoners met een arbeidsongeschiktheidsuitkering, oftewel 5 procent van het aantal inwoners dat tot de potentiële beroepsbevolking behoort.

- Dit percentage is lager dan het percentage in de bijbehorende COROP-regio Noord-Limburg $(6,6 \%)$ en tevens lager dan het percentage voor de provincie Limburg als geheel (8,8\%).

- Terwijl het percentage inwoners met een arbeidsongeschiktheidsuitkering in de provincie Limburg hoger is dan voor Nederland als geheel $(6,4 \%)$, is het percentage in de gemeente Horst aan de Maas min of meer gelijk aan dat voor Nederland als geheel.

- Van de inwoners met een arbeidsongeschiktheidsuitkering, woonachtig in de gemeente Horst aan de Maas, werkt 25,8 procent. Dit is hoger dan het percentage in de COROP-regio Noord-Limburg (20,6\%), hoger dan het percentage voor Limburg als geheel $(16,6 \%)$ en hoger dan het landelijk percentage (17,9\%).
Figuur 1 geeft voor iedere Limburgse gemeente het percentage inwoners weer dat een arbeidsongeschiktheidsuitkering ontvangt.

Uit Figuur 1 valt het volgende af te leiden:

- Het percentage inwoners met een arbeidsongeschiktheidsuitkering verschilt aanzienlijk tussen de Limburgse gemeentes.

- De gemeente Horst aan de Maas staat op de $2^{\mathrm{e}}$ plek in Limburg wat betreft het percentage inwoners met een arbeidsongeschiktheidsuitkering (gesorteerd van laag naar hoog).

Figuur 2 geeft de spreiding binnen de gemeente Horst aan de Maas weer in het percentage inwoners met een arbeidsongeschiktheidsuitkering.

Op basis van Figuur 2 kunnen we de volgende conclusies trekken:

- Binnen de gemeente Horst aan de Maas zijn er duidelijke verschillen te zien tussen de onderliggende wijken wat betreft het percentage inwoners met een arbeidsongeschiktheidsuitkering.

- Het percentage mensen met een arbeidsongeschiktheidsuitkering is het hoogst in de wijk Tienray (6,3\%).

- Omdat er voor enkele wijken geen data beschikbaar kon worden gesteld is het niet mogelijk om op betrouwbare wijze vast te stellen in welke wijk het percentage mensen met een arbeidsongeschiktheidsuitkering het laagst is. 


\section{Omvang risicogroepen in de Limburgse gemeente Horst aan de Maas}

FIGUUR 1.

Percentage inwoners met een arbeidsongeschiktheidsuitkering naar Limburgse gemeente

$14 \%$

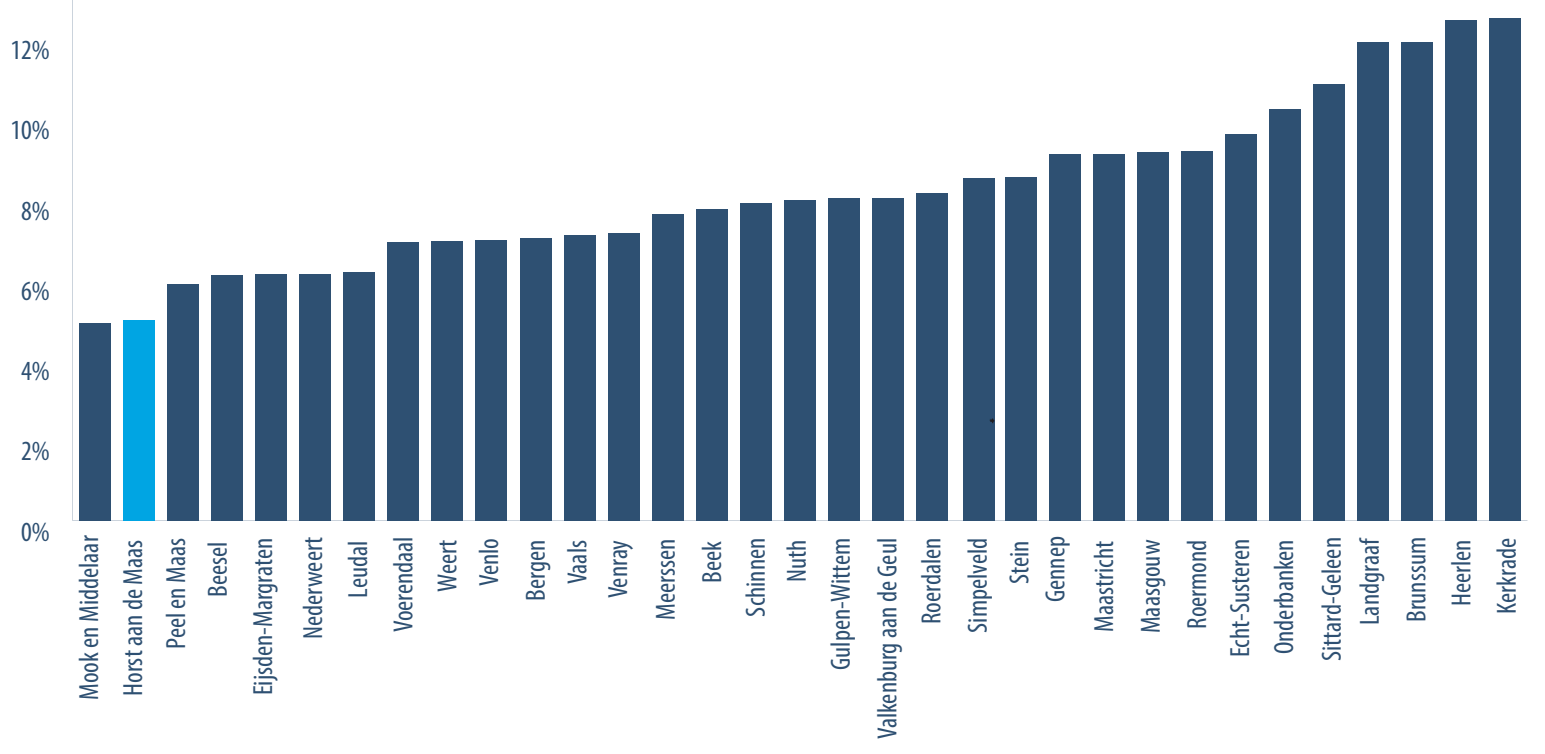

Bron: ROA, berekeningen op basis van microdata van het CBS

FIGUUR 2.

Percentage inwoners met een arbeidsongeschiktheidsuitkering naar wijk

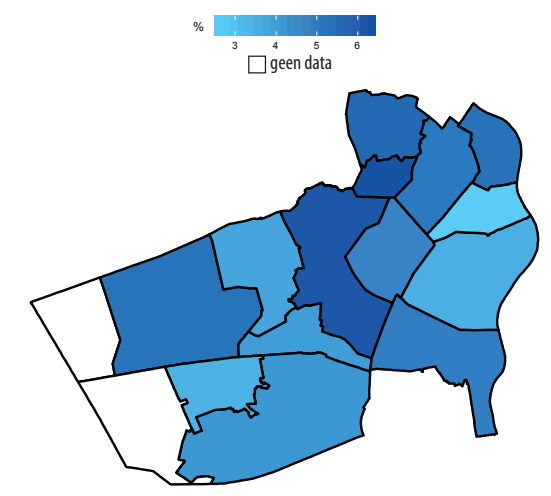

Bronnen: ROA, berekeningen op basis van microdata van het CBS; Kadaster/CBS, Wijk- en buurtkaart 2017 


\section{Inwoners met een werkloosheidsuitkering}

TABEL 2.

Overzicht van de absolute en relatieve omvang van inwoners met een werkloosheidsuitkering (WW-uitkering)

\begin{tabular}{|l|r|r|r|r|} 
& $\begin{array}{r}\text { Aantal inwoners met een } \\
\text { WW-uitkering }\end{array}$ & $\begin{array}{r}\text { Aantal inwoners behorend } \\
\text { tot de potentiële } \\
\text { beroepsbevolking }\end{array}$ & $\begin{array}{r}\text { Percentage inwoners met een } \\
\text { WW-uitkering }\end{array}$ & $\begin{array}{r}\text { Percentage werkenden onder inwoners } \\
\text { met een WW-uitkering }\end{array}$ \\
\hline Gemeente Horst aan de Maas & 783 & 28.145 & $2,8 \%$ & $51,7 \%$ \\
\hline Noord-Limburg & 5.469 & 187.721 & $2,9 \%$ & $50,6 \%$ \\
\hline Midden-Limburg & 3.826 & 157.217 & $2,4 \%$ & $51 \%$ \\
\hline Zuid-Limburg & 9.291 & 395.604 & $2,3 \%$ & $51,3 \%$ \\
\hline Limburg totaal & 18.586 & 740.542 & $2,5 \%$ & $51 \%$ \\
\hline Nederland totaal & 287.189 & 11.460 .361 & $2,5 \%$ & $47,6 \%$ \\
\hline
\end{tabular}

Bron: ROA, berekeningen op basis van microdata van het CBS

Tabel 2 geeft een overzicht van de omvang van het aantal personen met een werkloosheidsuitkering in de gemeente Horst aan de Maas. Ook hier worden de cijfers voor Horst aan de Maas in context geplaatst door ze te vergelijken met de cijfers voor de provincie Limburg als geheel en de drie onderliggende COROP-regio's Noord-, Midden- en Zuid-Limburg.

Uit Tabel 2 zijn een aantal conclusies te trekken:

- De gemeente Horst aan de Maas telde op 31 december 2017, 783 inwoners met een werkloosheidsuitkering, oftewel 2,8 procent van het aantal inwoners dat tot de potentiële beroepsbevolking behoort.

- Dit percentage is min of meer gelijk aan het percentage in de bijbehorende COROP-regio NoordLimburg (2,9\%) en tevens min of meer gelijk aan het percentage voor de provincie Limburg als geheel $(2,5 \%)$.

- Zowel in de gemeente Horst aan de Maas als in de provincie Limburg als geheel is het percentage inwoners met een werkloosheidsuitkering min of meer gelijk aan het landelijk gemiddelde (2,5\%).

- Van de inwoners met een werkloosheidsuitkering, woonachtig in de gemeente Horst aan de Maas, werkt 51,7 procent. Dit is min of meer gelijk aan het percentage in de COROP-regio Noord-Limburg $(50,6 \%)$, min of meer gelijk aan het percentage voor Limburg als geheel (51\%) en hoger dan het landelijk percentage $(47,6 \%)$.
Figuur 3 geeft voor iedere Limburgse gemeente het percentage inwoners weer dat een werkloosheidsuitkering ontvangt.

Uit Figuur 3 valt het volgende af te leiden:

- Het percentage inwoners met een werkloosheidsuitkering verschilt in beperkte mate tussen de Limburgse gemeentes.

- De gemeente Horst aan de Maas staat op de $28^{\mathrm{e}}$ plek in Limburg wat betreft het percentage inwoners met een werkloosheidsuitkering (gesorteerd van laag naar hoog).

Figuur 4 geeft de spreiding binnen de gemeente Horst aan de Maas weer in het percentage inwoners met een werkloosheidsuitkering.

Op basis van Figuur 4 kunnen we de volgende conclusies trekken:

- Binnen de gemeente Horst aan de Maas zijn er duidelijke verschillen te zien tussen de onderliggende wijken wat betreft het percentage inwoners met een werkloosheidsuitkering.

- Het percentage mensen met een werkloosheidsuitkering is het hoogst in de wijk America (3,8\%).

- Omdat er voor enkele wijken geen data beschikbaar kon worden gesteld is het niet mogelijk om op betrouwbare wijze vast te stellen in welke wijk het percentage mensen met een werkloosheidsuitkering het laagst is. 


\section{Omvang risicogroepen in de Limburgse gemeente Horst aan de Maas}

FIGUUR 3.

Percentage inwoners met een werkloosheidsuitkering naar Limburgse gemeente

$4 \%$

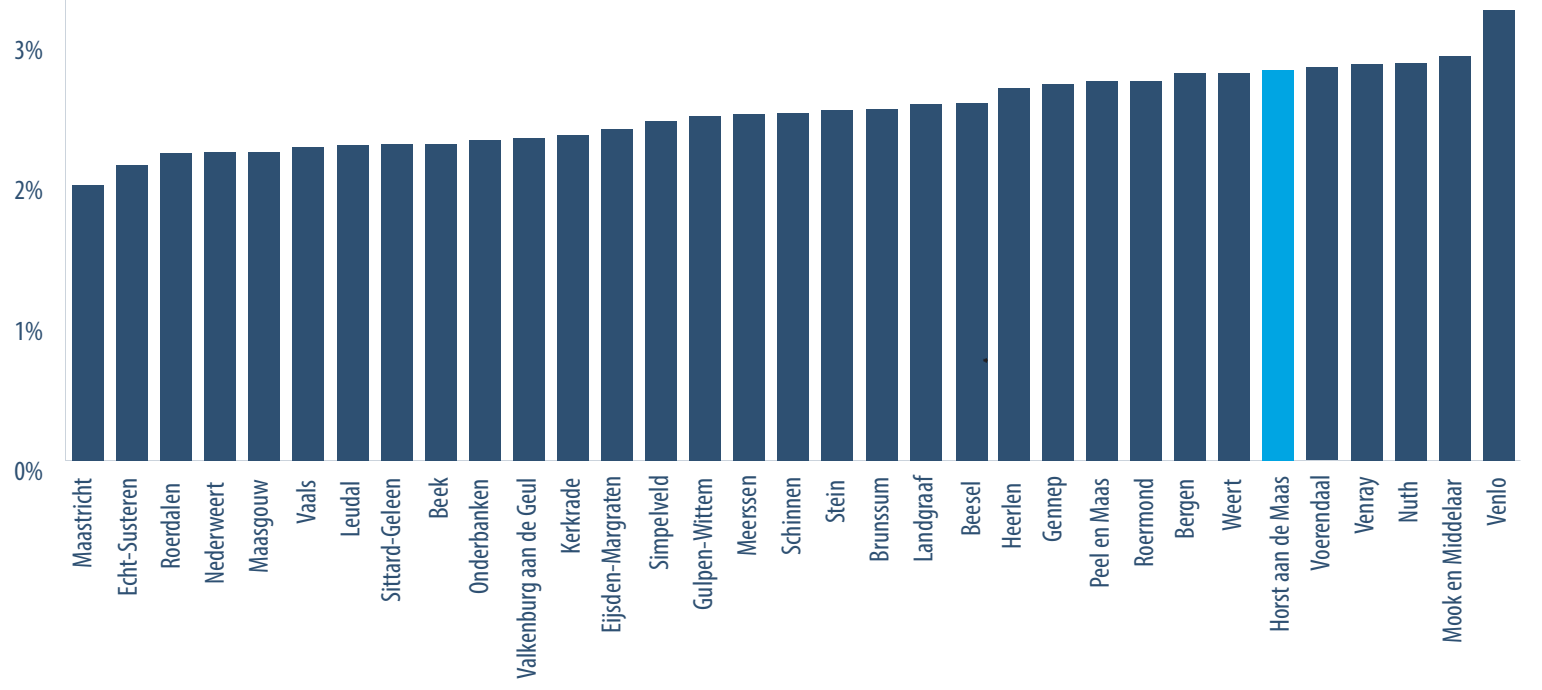

Bron: ROA, berekeningen op basis van microdata van het CBS

FIGUUR 4.

Percentage inwoners met een werkloosheidsuitkering naar wijk

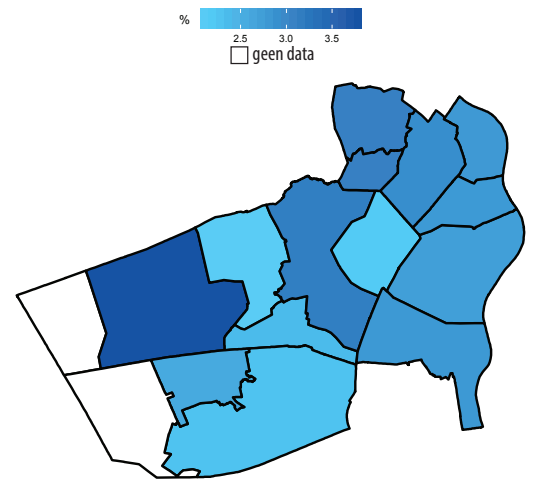

Bronnen: ROA, berekeningen op basis van microdata van het

CBS; Kadaster/CBS, Wijk- en buurtkaart 2017 


\section{Inwoners met een bijstandsuitkering}

TABEL 3.

Overzicht van de absolute en relatieve omvang van inwoners met een bijstandsuitkering

\begin{tabular}{|c|c|c|c|c|}
\hline & $\begin{array}{r}\text { Aantal inwoners met een } \\
\text { bijstandsuitkering }\end{array}$ & $\begin{array}{r}\text { Aantal inwoners } \\
\text { behorend tot } \\
\text { de potentiële } \\
\text { beroepsbevolking }\end{array}$ & $\begin{array}{r}\text { Percentage inwoners met een } \\
\text { bijstandsuitkering }\end{array}$ & $\begin{array}{r}\text { Percentage werkenden onder inwoners met } \\
\text { een bijstandsuitkering }\end{array}$ \\
\hline Gemeente Horst aan de Maas & 425 & 28.145 & $1,5 \%$ & $15,5 \%$ \\
\hline Noord-Limburg & 6.296 & 187.721 & $3,4 \%$ & $13,3 \%$ \\
\hline Midden-Limburg & 4.873 & 157.217 & $3,1 \%$ & $12,2 \%$ \\
\hline Zuid-Limburg & 19.344 & 395.604 & $4,9 \%$ & $8,9 \%$ \\
\hline Limburg totaal & 30.513 & 740.542 & $4,1 \%$ & $10,3 \%$ \\
\hline Nederland totaal & 479.069 & 11.460 .361 & $4,2 \%$ & $11,1 \%$ \\
\hline
\end{tabular}

Bron: ROA, berekeningen op basis van microdata van het CBS

Tabel 3 geeft een overzicht van de omvang van het aantal personen met een bijstandsuitkering in de gemeente Horst aan de Maas. Om de cijfers voor Horst aan de Maas in context te plaatsen worden ze wederom vergeleken met de cijfers voor de provincie Limburg als geheel en de drie onderliggende COROP-gebieden Noord-, Midden- en Zuid-Limburg.

Uit Tabel 3 zijn een aantal conclusies te trekken:

- De gemeente Horst aan de Maas telde op 31 december 2017, 425 inwoners met een bijstandsuitkering, oftewel 1,5 procent van het aantal inwoners dat tot de potentiële beroepsbevolking behoort.

- Dit percentage is lager dan het percentage in de bijbehorende COROP-regio Noord-Limburg $(3,4 \%)$ en tevens lager dan het percentage voor de provincie Limburg als geheel $(4,1 \%)$.

- Terwijl het percentage inwoners met een bijstandsuitkering in de provincie Limburg min of meer gelijk is aan dat voor Nederland als geheel $(4,2 \%)$, is dit percentage in de gemeente Horst aan de Maas lager dan dat voor Nederland als geheel.

- Van de inwoners met een bijstandsuitkering, woonachtig in de gemeente Horst aan de Maas, werkt 15,5 procent. Dit is hoger dan het percentage in de COROP-regio Noord-Limburg (13,3\%), hoger dan het percentage voor Limburg als geheel (10,3\%) en hoger dan het landelijk percentage $(11,1 \%)$.
Figuur 5 geeft voor iedere Limburgse gemeente het percentage inwoners weer dat een bijstandsuitkering ontvangt.

Uit Figuur 5 valt het volgende af te leiden:

- Het percentage inwoners met een bijstandsuitkering verschilt aanzienlijk tussen de Limburgse gemeentes.

- De gemeente Horst aan de Maas staat op de $2^{\mathrm{e}}$ plek in Limburg wat betreft het percentage inwoners met een bijstandsuitkering (gesorteerd van laag naar hoog).

Figuur 6 geeft de spreiding binnen de gemeente Horst aan de Maas weer in het percentage inwoners met een bijstandsuitkering.

Op basis van Figuur 6 kunnen we de volgende conclusies trekken:

- Binnen de gemeente Horst aan de Maas zijn er duidelijke verschillen te zien tussen de onderliggende wijken wat betreft het percentage inwoners met een bijstandsuitkering.

- Het percentage mensen met een bijstandsuitkering is het hoogst in de wijk Horst $(2,4 \%)$.

- Omdat er voor enkele wijken geen data beschikbaar kon worden gesteld is het niet mogelijk om op betrouwbare wijze vast te stellen in welke wijk het percentage mensen met een bijstandsuitkering het laagst is. 


\section{Omvang risicogroepen in de Limburgse gemeente Horst aan de Maas}

FIGUUR 5.

Percentage inwoners met een bijstandsuitkering naar Limburgse gemeente

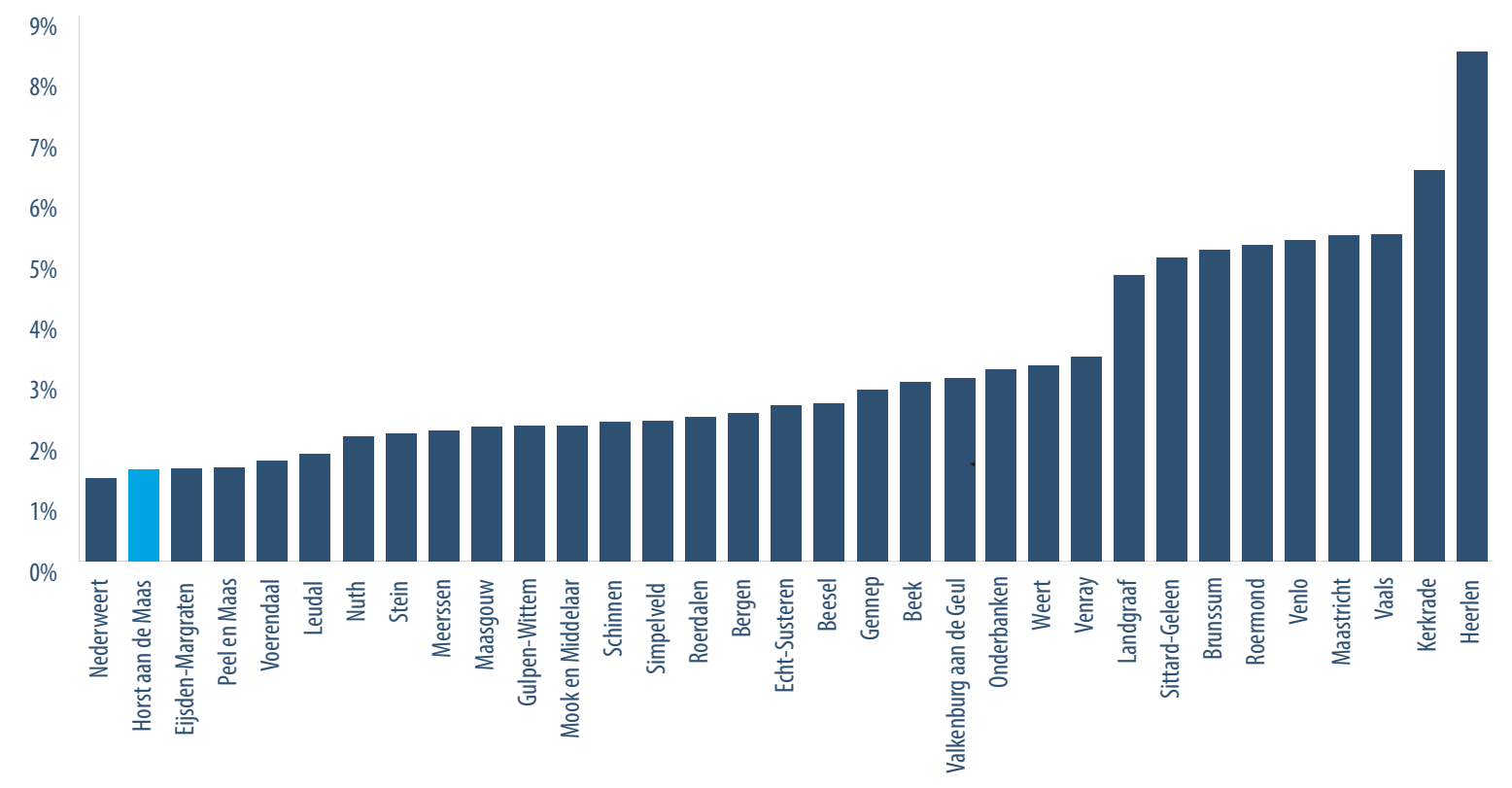

Bron: ROA, berekeningen op basis van microdata van het CBS

FIGUUR 6.

Percentage inwoners met een bijstandsuitkering naar wijk

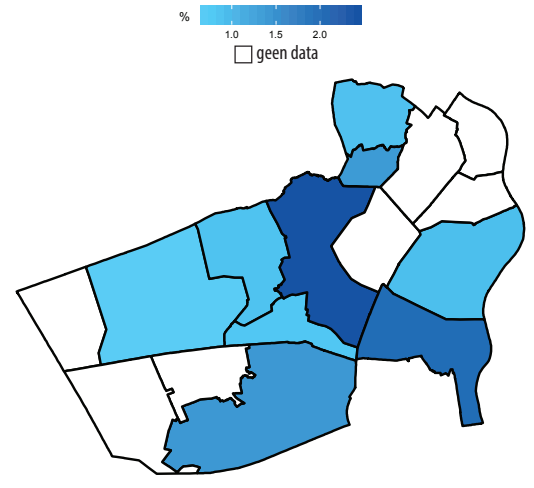

Bronnen: ROA, berekeningen op basis van microdata van het CBS; Kadaster/CBS, Wijk- en buurtkaart 2017 


\section{Inactieve inwoners die geen uitkering ontvangen of initieel onderwijs volgen}

TABEL 4 .

Overzicht van de absolute en relatieve omvang van inactieve inwoners zonder uitkering

\begin{tabular}{|l|r|r|r|} 
& Aantal inactieve inwoners & Aantal inwoners behorend tot de potentiële & Percentage inactieve inwoners \\
beroepsbevolking & 28.145 & $5,2 \%$ \\
\hline Gemeente Horst aan de Maas & 1.462 & 187.721 & $6,4 \%$ \\
\hline Noord-Limburg & 11.934 & 157.217 & $7 \%$ \\
\hline Midden-Limburg & 10.976 & 395.604 & $8,3 \%$ \\
\hline Zuid-Limburg & 32.869 & 740.542 & $7,5 \%$ \\
\hline Limburg totaal & 55.779 & 11.460 .361 & $7,1 \%$ \\
\hline Nederland totaal & 813.554 & & \\
\hline
\end{tabular}

Bron: ROA, berekeningen op basis van microdata van het CBS

Tabel 4 geeft een overzicht van de omvang van het aantal inactieve personen in de gemeente Horst aan de Maas. Zoals eerder aangegeven gaat hierbij om personen die inactief zijn op de arbeidsmarkt zonder dat zij onderwijs volgen of een arbeidsongeschiktheidswerkloosheids- of bijstandsuitkering ontvangen. Personen die de AOW-gerechtigde leeftijd reeds hebben bereikt en personen die een pensioenuitkering ontvangen worden niet als inactief beschouwd.

Om de cijfers voor Horst aan de Maas in context te plaatsen worden ze ook hier weer vergeleken met de cijfers voor de provincie Limburg als geheel en de drie onderliggende COROP-gebieden Noord-, Midden- en Zuid-Limburg.

Uit Tabel 4 zijn een aantal conclusies te trekken:

- De gemeente Horst aan de Maas telde op 31 december 2017, 1.462 inactieve inwoners, oftewel 5,2 procent van het aantal inwoners dat tot de potentiële beroepsbevolking behoort.

- Dit percentage is min of meer gelijk aan het percentage in de bijbehorende COROP-regio NoordLimburg $(6,4 \%)$, maar lager dan het percentage voor de provincie Limburg als geheel $(7,5 \%)$.

- Terwijl het percentage inactieve inwoners in de provincie Limburg min of meer gelijk is aan dat voor Nederland als geheel $(7,1 \%)$, is dit percentage in de gemeente Horst aan de Maas lager dan dat voor Nederland als geheel.
Figuur 7 geeft voor iedere Limburgse gemeente het percentage inactieve inwoners weer. Uit de figuur valt het volgende af te leiden:

- Het percentage inactieve inwoners verschilt aanzienlijk tussen de Limburgse gemeentes.

- De gemeente Horst aan de Maas staat op de $1^{\mathrm{e}}$ plek in Limburg wat betreft het percentage inactieve inwoners (gesorteerd van laag naar hoog).

Figuur 8 geeft de spreiding binnen de gemeente Horst aan de Maas weer in het percentage inactieve inwoners.

Op basis van Figuur 8 kunnen we de volgende conclusies trekken:

- Binnen de gemeente Horst aan de Maas zijn er duidelijke verschillen te zien tussen de onderliggende wijken wat betreft het percentage inactieve inwoners.

- Het percentage inactieve personen is het hoogst in de wijk Evertsoorsd (23,1\%).

- Het percentage inactieve personen is het laagst in de wijk Melderslo (3,9\%). 


\section{Omvang risicogroepen in de Limburgse gemeente Horst aan de Maas}

FIGUUR 7.

Percentage inactieve inwoners zonder uitkering naar Limburgse gemeente

$14 \%$

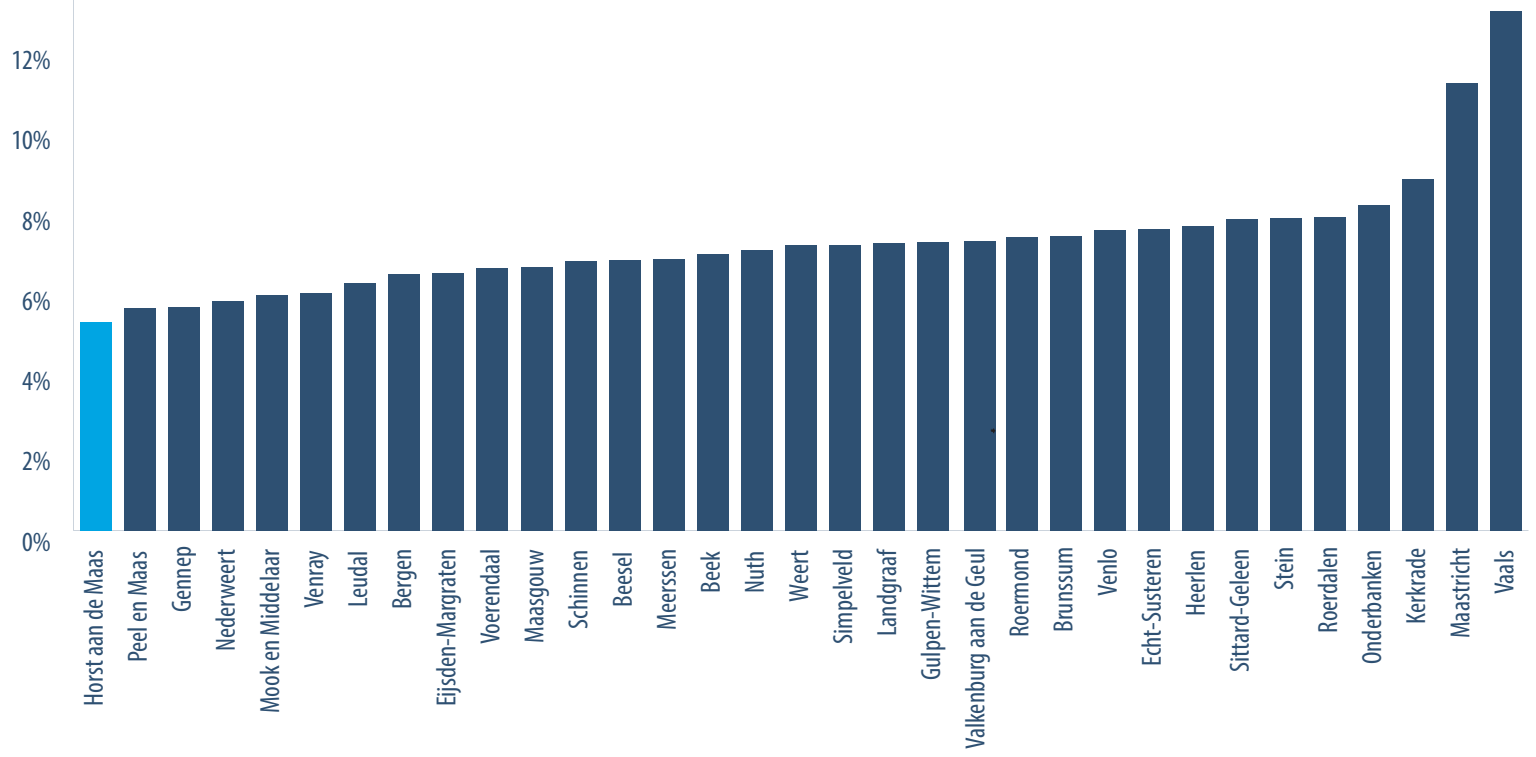

Bron: $\mathrm{ROA}$, berekeningen op basis van microdata van het CBS

FIGUUR 8.

Percentage inactieve inwoners zonder uitkering naar wijk
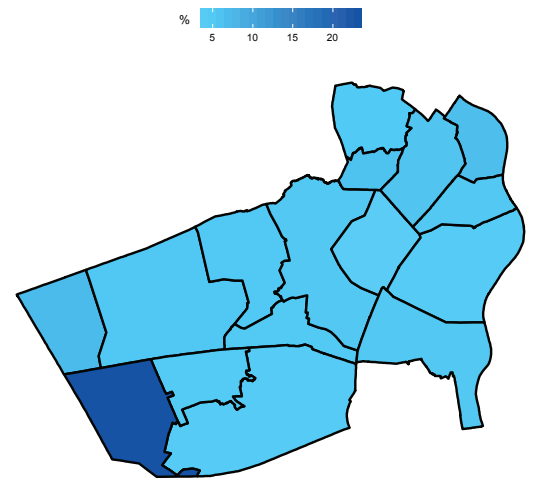

Bronnen: ROA, berekeningen op basis van microdata van het CBS; Kadaster/CBS, Wijk- en buurtkaart 2017 


\section{Factsheet}

ROA-F-2019/3 - Horst aan de Maas

\section{Totale groep inwoners in een risicopositie}

TABEL 5.

Overzicht van de absolute en relatieve omvang van inwoners in een risicopositie

\begin{tabular}{|l|r|r|r|r|} 
& Aantal inwoners in een risicopositie & $\begin{array}{r}\text { Aantal inwoners behorend tot de } \\
\text { potentielle beroepsbevolking }\end{array}$ & $\begin{array}{r}\text { Percentage inwoners in een } \\
\text { risicopositie }\end{array}$ & $\begin{array}{r}\text { Percentage werkenden } \\
\text { onder inwoners in een } \\
\text { risicopositie }\end{array}$ \\
\hline Gemeente Horst aan de Maas & 4.041 & 28.145 & $14,4 \%$ & $20,4 \%$ \\
\hline Noord-Limburg & 35.702 & 187.721 & $19 \%$ & $17,1 \%$ \\
\hline Midden-Limburg & 31.996 & 157.217 & $20,4 \%$ & $14,8 \%$ \\
\hline Zuid-Limburg & 100.154 & 395.604 & $25,3 \%$ & $12,3 \%$ \\
\hline Limburg totaal & 167.852 & 740.542 & $22,7 \%$ & $13,8 \%$ \\
\hline Nederland totaal & 2.286 .183 & 11.460 .361 & $19,9 \%$ & $13,9 \%$ \\
\hline
\end{tabular}

Bron: ROA, berekeningen op basis van microdata van het CBS

Hierboven werden achtereenvolgens telkens één van de vier risicogroep geïsoleerd in kaart gebracht. Tabel 5 geeft een overzicht van de totale groep mensen in een risicopositie voor de gemeente Horst aan de Maas. Het betreft hier personen die ófwel één of meerdere van de onderscheiden uitkeringstypes ontvangen óf inactief zijn op de arbeidsmarkt. Omdat individuen tegelijkertijd meerdere uitkeringen kunnen ontvangen wijkt de totale groep inwoners in een risicopositie af van de optelsom van de afzonderlijke uitkeringsontvangers en inactieven. Om de cijfers voor Horst aan de Maas in context te plaatsen worden ze uiteraard weer vergeleken met cijfers voor de provincie Limburg als geheel en de drie onderliggende COROP-regio's Noord, Midden en ZuidLimburg.

Uit Tabel 5 zijn een aantal conclusies te trekken:

- In totaal bevinden 4.041 personen, oftewel 14,4 procent van de 15- tot en met 67-jarige inwoners, in de gemeente Horst aan de Maas zich in een risicopositie.

- Het percentage inwoners in een risicopositie is hiermee lager dan dat van de bijbehorende COROP-regio Noord-Limburg (19\%), lager dan het percentage in de provincie Limburg als geheel $(22,7 \%)$ en lager dan het landelijke percentage (19,9\%).

- Van de inwoners behorend tot een risicogroep, woonachtig in de gemeente Horst aan de Maas, werkt 20,4 procent. Dit is hoger dan het percentage in de COROP-regio Noord-Limburg $(17,1 \%)$, hoger dan het percentage voor Limburg als geheel $(13,8 \%)$ en hoger dan het landelijk percentage (13,9\%).
Figuur 9 geeft voor iedere Limburgse gemeente het percentage inwoners in een risicopositie weer. Uit de figuur valt het volgende af te leiden:

- Het percentage inwoners in een risicopositie verschilt aanzienlijk tussen de Limburgse gemeentes.

- De gemeente Horst aan de Maas staat op de $1^{\mathrm{e}}$ plek in Limburg wat betreft het percentage inwoners in een risicopositie (gesorteerd van laag naar hoog).

Figuur 10 geeft de spreiding binnen de gemeente Horst aan de Maas weer in het percentage inwoners in een risicopositie.

Op basis van Figuur 10 kunnen we de volgende conclusies trekken:

- Binnen de gemeente Horst aan de Maas zijn er duidelijke verschillen te zien tussen de onderliggende wijken wat betreft het percentage inwoners in een risicopositie.

- Het percentage personen in een risicopositie is het hoogst in de wijk Evertsoorsd (27,6\%).

- Het percentage personen in een risicopositie is het laagst in de wijk Kronenberg (10,6\%). 


\section{Omvang risicogroepen in de Limburgse gemeente Horst aan de Maas}

FIGUUR 9.

Percentage inwoners in een risicopositie naar Limburgse gemeente

$35 \%$

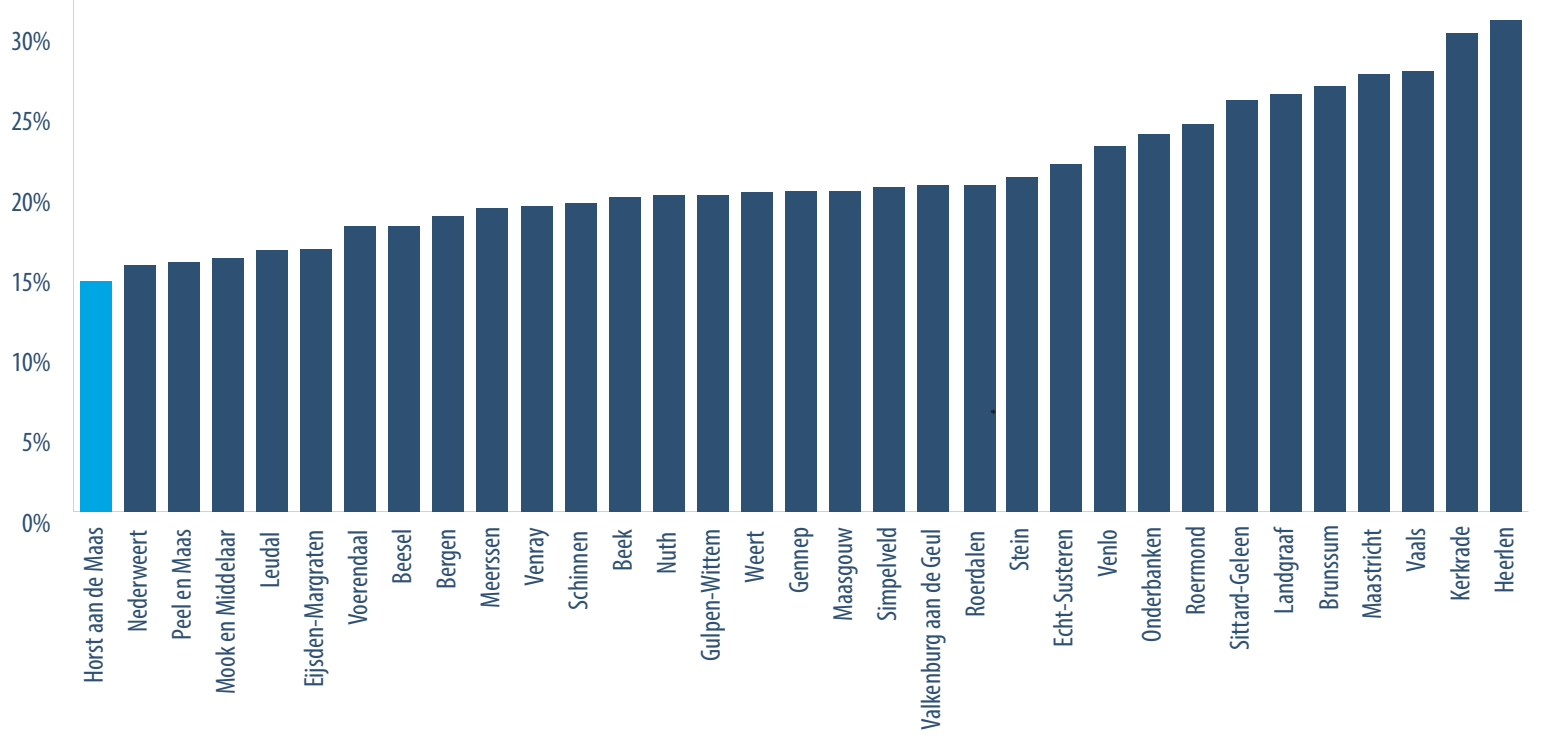

Bron: ROA, berekeningen op basis van microdata van het CBS

FIGUUR 10.

Percentage inwoners in een risicopositie naar wijk
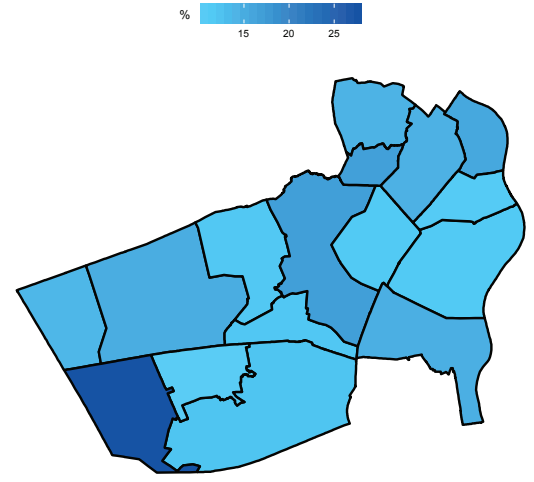

Bronnen: ROA, berekeningen op basis van microdata van het CBS; Kadaster/CBS, Wijk- en buurtkaart 2017 


\section{4LIMBURG}

Deze factsheet is een onderdeel van het meerjarenprogramma 4 Limburg dat een bijdrage wil leveren om de Limburgse samenleving meer duurzaam, vitaal en inclusief te maken. Het doel van dit programma is om, in nauwe samenwerking met de Universiteit Maastricht, Provincie Limburg en ketenpartners zoals gemeenten, UWV en bedrijfsleven, via een trendbreuk de arbeidsparticipatie én de vitaliteit in Limburg naar een hoger niveau te tillen. Er zijn in Limburg veel mensen zonder werk onder de potentiële beroepsbevolking. Inzicht in de omvang en complexiteit van de groep uitkeringsontvangers en de groep inactieven die geen uitkering ontvangen en geen initieel onderwijs volgen is nodig alvorens initiatieven kunnen zorgen voor een inclusieve arbeidsmarkt waar iedereen in kan participeren. Deze factsheet heeft als doel de omvang van deze risicogroepen in de gemeente Horst aan de Maas in kaart te brengen. Mogelijk zal later dit jaar de complexiteit van de problematiek van degenen die tot een risicogroep behoren in een factsheet voor de Provincie Limburg in kaart gebracht worden.

\section{Colofon}

๑) Researchcentrum voor Onderwijs en Arbeidsmarkt Niets uit deze uitgave mag op enige manier worden verveelvoudigd zonder voorafgaande schriftelijke toestemming van de directeur van het ROA.

Researchcentrum voor Onderwijs en Arbeidsmarkt

Maastricht University

School of Business and Economics

secretary-roa-sbe@maastrichtuniversity.n

www.roa.nl

\section{Vormgeving}

ROA secretariaat, Maastricht 